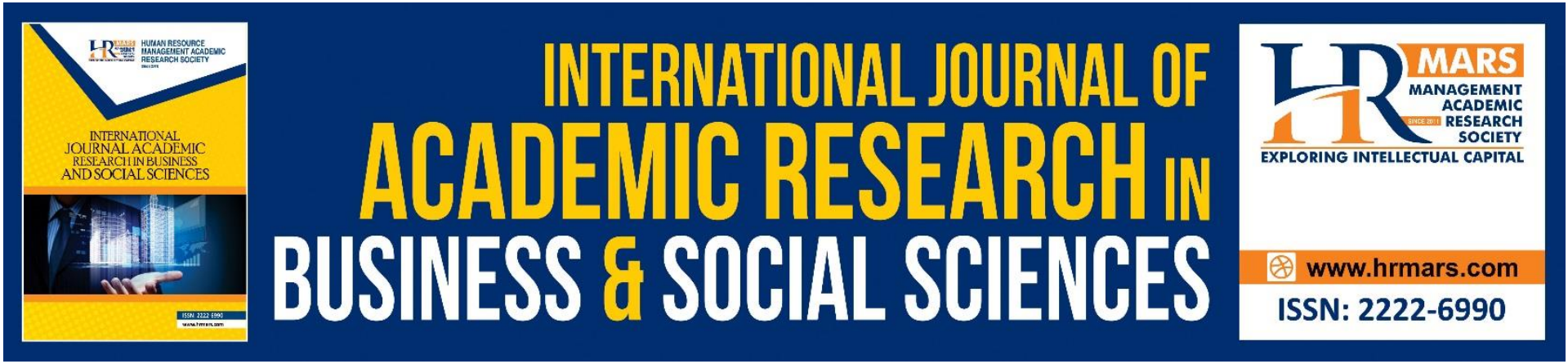

\title{
Digital Media Platform as Online Food Taste Stimulator: A Proposed Conceptual Model
}

Nur Hasni Nasrudin, Afdallyna Fathiyah Harun, Wan Abdul Rahim Wan Mohd Isa

To Link this Article: http://dx.doi.org/10.6007/IJARBSS/v11-i12/11981

DOI:10.6007/IJARBSS/v11-i12/11981

Received: 18 October 2021, Revised: 21 November 2021, Accepted: 04 December 2021

Published Online: 23 December 2021

In-Text Citation: (Nasrudin et al., 2021)

To Cite this Article: Nasrudin, N. H., Harun, A. F., \& Isa, W. A. R. W. M. (2021). Digital Media Platform as Online Food Taste Stimulator: A Proposed Conceptual Model. International Journal of Academic Research in Business and Social Sciences, 11(12), 2503-2513.

Copyright: (c) 2021 The Author(s)

Published by Human Resource Management Academic Research Society (www.hrmars.com)

This article is published under the Creative Commons Attribution (CC BY 4.0) license. Anyone may reproduce, distribute, translate and create derivative works of this article (for both commercial and non0-commercial purposes), subject to full attribution to the original publication and authors. The full terms of this license may be seen at: http://creativecommons.org/licences/by/4.0/legalcode

Vol. 11, No. 12, 2021, Pg. 2503- 2513

Full Terms \& Conditions of access and use can be found at http://hrmars.com/index.php/pages/detail/publication-ethics 


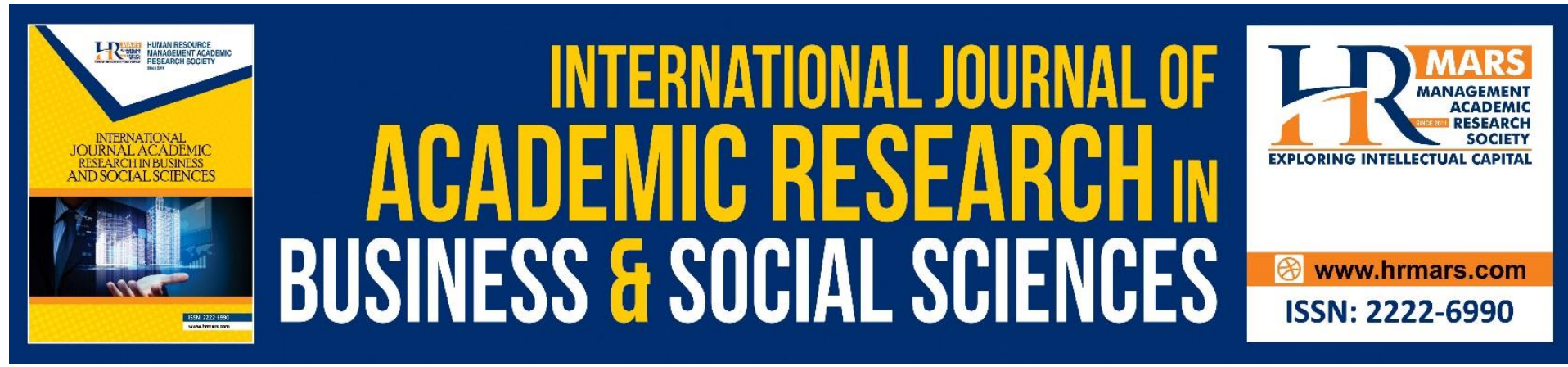

\title{
Digital Media Platform as Online Food Taste Stimulator: A Proposed Conceptual Model
}

\author{
Nur Hasni Nasrudin, Afdallyna Fathiyah Harun, Wan Abdul \\ Rahim Wan Mohd Isa
}

Faculty of Computer and Mathematical Sciences, Universiti Teknologi MARA, Malaysia Email: afdallyna@tmsk.uitm.edu.my (corresponding author)

\begin{abstract}
The social media and its visual content serve as a great platform for digital marketing. However, many may inadvertently miss the opportunity to stimulate food taste experience using visuals as the attribute. This paper presents a conceptual model that can serve as a reference on visual attributes that should be considered when using digital images to stimulate taste experience via digital platform. Using qualitative approach, we undertook three major steps; a literature review of related research was conducted to capture the positioning of digital platform in sharing food or taste experience, an expert interview with a professional food photographer to gain his insight and experience on data visual strategies, and finally the findings from both sources led to conceptual modelling highlighting not only technical consideration but also philosophical motivation in constructing a visual image that stimulates taste experience. We found that food visuals could trigger food taste experience provided elements such as lighting, focus, color, framing, visual perception theory and social media ethics are accommodated. Nevertheless, the conceptual model is still in its infancy, with further studies required to enhance the proposed model.
\end{abstract}

Keywords: Visuals in Social Media, Taste Experience, Conceptual Model, Food Visuals, Visual Cognition, Sensory Perception, $\mathrm{HCl}$, UX

\section{Introduction}

The rise of social media users has dramatically increased, and it is expected that (both current and future) features of social media sites play important roles in providing smooth interactions and joyful experience, key features to user satisfaction (Othman et al., 2019). The study in social media trend has changed from unimodal approaches which focused on text (Bruns \& Burgess, 2015) to multimodal approaches. The transformation is a reflection of user behaviour to visual information (Marr, 2010; Zhang, 2018) signifying key growth of visual content (Highfield \& Leaver, 2016; Pearce et al., 2020). In fact, Gretzel (2017) believed that visuals have taken a turn in social media, in which Instagram has become a dominant player where individuals' experiences are visualized across social media platforms (Mara, 2019; Pearce et al., 2020).

Vision has portrayed itself as a powerful attribute as findings found that $94 \%$ more views will be attained when relevant visuals is used in the advertisement (Bradley, 2014; 
Elson, 2019). This attest the significance of visuals in social media playing a dominant impact in digital marketing (Chaffey, 2019; Gretzel, 2017; Noronha et al., 2011; Twente, 2019) particularly in the food industries (Bublitz \& Peracchio, 2015; Culinary, Alliance, \& Present, 2015; Kopcok, 2019). It is unsurprising then to find food photographs as amongst the most uploaded images on social media (Yong, Tong, \& Liu, 2020) with visually appealing food often going viral (Fox et al., 2018).

Producing an appealing food visuals in social media has its set of challenges calling for a comprehensive visual strategy to engage consumer with visual content (Gretzel, 2017). This is even more vital when 'visual hunger' phenomenon exist; consumers often want to know the taste of the food they see in digital means (Spence, Okajima, Cheok, Petit, \& Michel, 2015). This is sensory cognition - the ability to make decisions based on stimuli input (Witthoft et al., 2018).

Multimodal experience is put forth in order to support the multisensory interactions. We are stimulated by visuals, auditory, touch and smell with cross-modal computer interactions are in place to support stimulus timing pertaining to user's task (Gregory \& Dai, 2015). When it comes to visual communication, visual sensory takes precedence. A digital platform must highlight visual elements and adopt visual interaction strategies in enabling perception, inferences and ultimately, decision making (Steichen et al., 2020).

This brings us to the problem context of our research. We opine that at present, using social media for food images is limited to visual presentation and experience sharing. It lacks the ability to augment the taste experience that could be experienced by the image consumers. This is attributed to the present platform design as well as the nature of image displays. It begets the question "How do we support perception and inference making process through visual interaction on a digital site so users would be able to make an accurate taste perception?" We implore that to address this, we need to investigate the digital image construction as well as the digital platform design. Both dimensions are inter-related as we need to take into consideration how best to construct a digital image for placement on the web and how can the web design further augment the taste data embedded within the image for consumers to build perception.

Food's taste experience can only be stimulated if the relevant and right visual cues are in place. This is drawn from evidence where images have been proven as an essential component for successful media website (Garcia-Burgos, Lao, Munsch, \& Caldara, 2017). Therefore, we are motivated to investigate the elements crucial in constructing a digital image that could stimulate food taste experience. It is important to address the object stimulant here as it is a form of data presentation. In Human Computer Interaction, user centric data presentation allows visual interaction, and that the interaction is enabled right from the visualization process of converting raw data (in our case, the taste) into data view (in our case, the visual presentation) and ultimately the decision making (Dimara \& Perin, 2020). The operational process into the data itself would extend to the semantic interaction of the presented data (Endert, Fiaux, \& North, 2012). Therefore, the focus of this paper is to discuss how the object stimulant must be designed to enable taste simulation. We approached this with literature search from published journal and proceeding papers coupled with expert interview with professional food photographer. The resulting conceptual model outlines how the food visual image (data object) could be manufactured serving as a guideline for practitioners, marketers or data designers. 


\section{Method}

This research is qualitative research involving two data collection methods - literature review and expert interview. The findings from both secondary and primary data are analysed resulting into a conceptual model. The details of every method and the development process of the conceptual model are explained in the following sections.

\section{Literature Review}

Based on our extensive but limited search query, we have yet to find a digital platform positioned to stimulate food taste experience. Therefore, we use social media as the basis for our literature search in terms of digital platform. This is because, social media has largely been the platform for users to post their food purchases, adventures, and experience (Peng, 2019). As the aim of literature review is to build up an understanding and collecting related facts about role of visuals in food experience, we believe that social media platform as image mediator can serve as a reference point for our digital platform design consideration. This is because, social media is a web-based media platform with high number of users. Additionally, it is through social media where images are largely shared with Instagram the most significant player.

In our literature review, we explored on social media trends, the role of visuals in social media as well as food taste experience terminologies and concepts in social media. On the other hand, the literature review exercise helps to identify the gap in the media use for capturing human food taste experience. This is turn helps to determine the elements and underlying theories in representing human taste experience in social media. The literature search was performed in Google Scholar (https://scholar.google.com/) as well as in Science Direct (https://www.sciencedirect.com/). Then all related facts and finding are cited and recorded in the excel format for retrieval and future use.

\section{Expert Interview}

The expert interviewed in this research was Mohd Azhar Mohammad Saini, a professional food photographer as well as the owner of Azhar Saini Training \& Consultancy. He has wide experience and is often invited to provide smartphone photography consultations and workshops. His photography portfolio began since 1997 and has authored the "Snape jer Dari snapshot ke great shot" book. Interestingly, he himself actively shares his photography artifacts and photography tips in social media. As a key expert (Libakova \& Sertakova, 2015) he was able to give solid structure to the account of food visual preparation as he has professional knowledge and wide experience in this field. The expert gave excellent commitment and comprehensive answers as well as suggestions during his 50 minutes online interview session. The interview questions include the minimum smartphone requirement for food photography, handling photography elements to trigger food taste in the picture, the editing application in smartphone to enhance food picture, fake pictures as well as ethics in food photography.

\section{Conceptual Modeling}

We derived the conceptual model by comparing and analyzing the findings from both the literature review and expert interview. The visualization of this process can be seen from Fig 1. Comparison between the findings of literature review and expert interview was done by identifying the similarities and differences. This comparison would allow us to gauge the theoretical underpinning and practical application of visual data creation. The expert insight 
is particularly critical as we had intended to derive attributes that can be applied by the public and not just the professionals when it comes to manufacturing visual food data that stimulates taste.

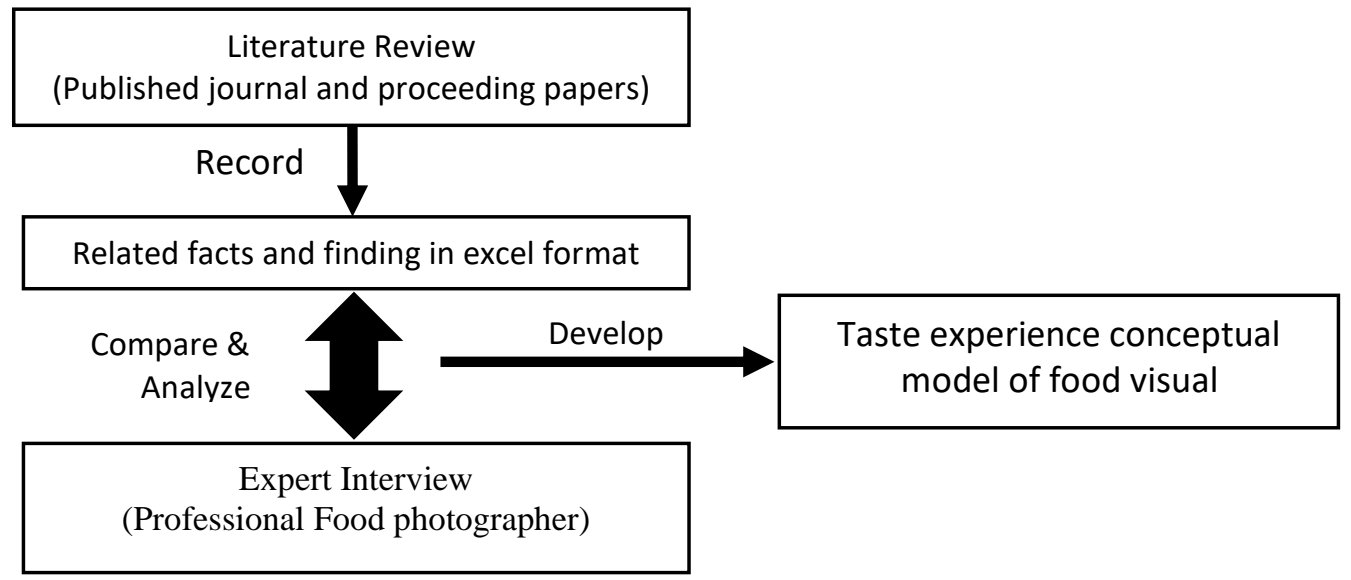

Fig.1: the overall research method in this research

\section{Results and Discussion}

Findings indicate that social media usage are increasing with smartphones acting as the dominant driver (Ilter \& Karacar, 2019; Serafinelli, 2017). The camera lens on smartphone is a powerful and primary input device to capture visuals (Kjeldskov, 2019; Science, 2019) with market trends offering varying smartphone model over the past few years (Feng \& Yu, 2020). However, the device is only an end to a mean. According to the expert interview, basic skills and knowledge play critical roles to capture food visuals with good quality.

A basic knowledge in photography means to know what should be considered in photography. We also discussed about the photography elements that should be considered to trigger a good digital food visual. The findings are summarized in Table 1 with reference 1 referring to visual elements in photography by Weebly (2019); reference 2 referring to photography tips by USDACenter (2017) and finally the last column represents tip insights from the expert interview. Generally, the expert agrees with Weebly (2019) but emphasised that plating style is a vital element in food visuals. He further explained that food texture can be stimulated by applying the right focus on the food product. While time according to expert relate with lighting which in Malaysia the best time is at $7.30 \mathrm{am}-9.30 \mathrm{am}$ and $4.00 \mathrm{pm}-$ $6.30 \mathrm{pm}$. Therefore, time falls under lighting element. Overall, it can be concluded that all three sources are generally similar with very minimal differences. It is also important to add that literature review have also discussed on the importance of photography ethics as unethical photography could risk and jeopardize the integrity of the industry as a whole (Ethics, 2018; Vujovic, 2018). 
TABLE 1: The photography elements from three sources

\begin{tabular}{|l|l|l|}
\hline Reference 1 & Reference 2 & Expert \\
\hline Lighting & Food theme & Lighting \\
\hline Texture & Lighting & Plating style \\
\hline Focus & Planning & Focus \\
\hline Angle of view & $\begin{array}{l}\text { Composition and } \\
\text { styling }\end{array}$ & Angle of view \\
\hline Color & $\begin{array}{l}\text { Keep nutrition in } \\
\text { mind }\end{array}$ & Color \\
\hline Framing/composition & & Framing/composition \\
\hline Time & & \\
\hline
\end{tabular}

Previous study has shown that food digital image has a good performance to stimulate food taste experience (Nasrudin \& Harun, 2020). However, the findings were not consistent in a different study conducted where it was found that the lack of actual taste experience by users could result into wrong taste perception if relying on food visuals alone (Harun et al., 2020). It is because perception depends on individual cognition process that rely on their knowledge, experience Seo \& Yun (2015) as well as emotion and memory (Williams, 2018). We found that visual perception theory may help to facilitate individuals in making perception and should be considered during visual preparation. This theory has been used to develop conceptual frameworks of marketing context. Hence, we believe it is also suitable to be included in producing taste experience conceptual model of food visuals to compliment the photography ethics.

There are many smartphone applications available to produce beautiful and appealing food visuals (Kopcok, 2019) with features such as blend images, accompanying text with original photo as well as adjusting photo brightness and tone (Hull, 2019). Undeniably, the right editing technique will result in a good quality food visual that have the possibility to go viral. However, erroneous photo technique judgment could lead to false taste perception and worst, too much doctoring on the visuals could produce false impression on the food's taste (Ferro, 2014). Henceforth, as part of our proposed conceptual framework visual editing activities with social media ethics from Islamic perspectives by Mansor et al (2020) should be considered as part of food data capture.

Our proposed conceptual model of producing food visual data to stimulate taste experience is illustrate in Fig. 3. The model encapsulates photo capture process which are (i) taking the picture, (ii) picture editing, and (iii) sharing picture to social media (i.e. digital platform). The model also considers viewers perception to the image, specifically on how their cognitive abilities could be supported so the right taste is accurately perceived by them.

We argued that in a visual communication, visual sensory takes precedence and as the subject matter is on taste perception, the visuals must have the ability to augment the required taste. We would like to emphasize again that we are looking at the image as a form of data management as it will serve as the object stimulant for the image consumers. We believe that our proposed conceptual model would help achieve this.

Our conceptual model suggests that in capturing the food visuals, there are six (6) visual elements that must be in place. These are lighting, view of angle, focus, color, plating style; and framing/composition. Harun et al (2020); Okajima \& Spence (2011) have found that 
a food photo image may be perceived differently by different users as each of them have their own perception and expectations. Therefore, visual perception theory is an important consideration in order to ensure that the visual capture could match viewers' perception and expectation. Additionally, it is also very important for photographers to comply with photography ethics to produce an honest visual. Although visual editing can enhance the subject matter, there is a need for control so visuals will not be overly modified. Social media ethics from Islamic perspective (Mansor, Narawi, \& Bayoumi, 2020) could be adapted during editing and sharing process to achieve visual honesty.

On the image consumer side, their taste perception is made based on their memories, knowledge, experience, and emotion. We believe their cognitive ability to make correct perception can be supported if the food visuals are prepared by understanding and applying the visuals elements, visual perception theory and visual ethics as discussed earlier. 
INTERNATIONAL JOURNAL OF ACADEMIC RESEARCH IN BUSINESS AND SOCIAL SCIENCES Vol. 11, No. 12, 2021, E-ISSN: 2222-6990 @ 2021 HRMARS

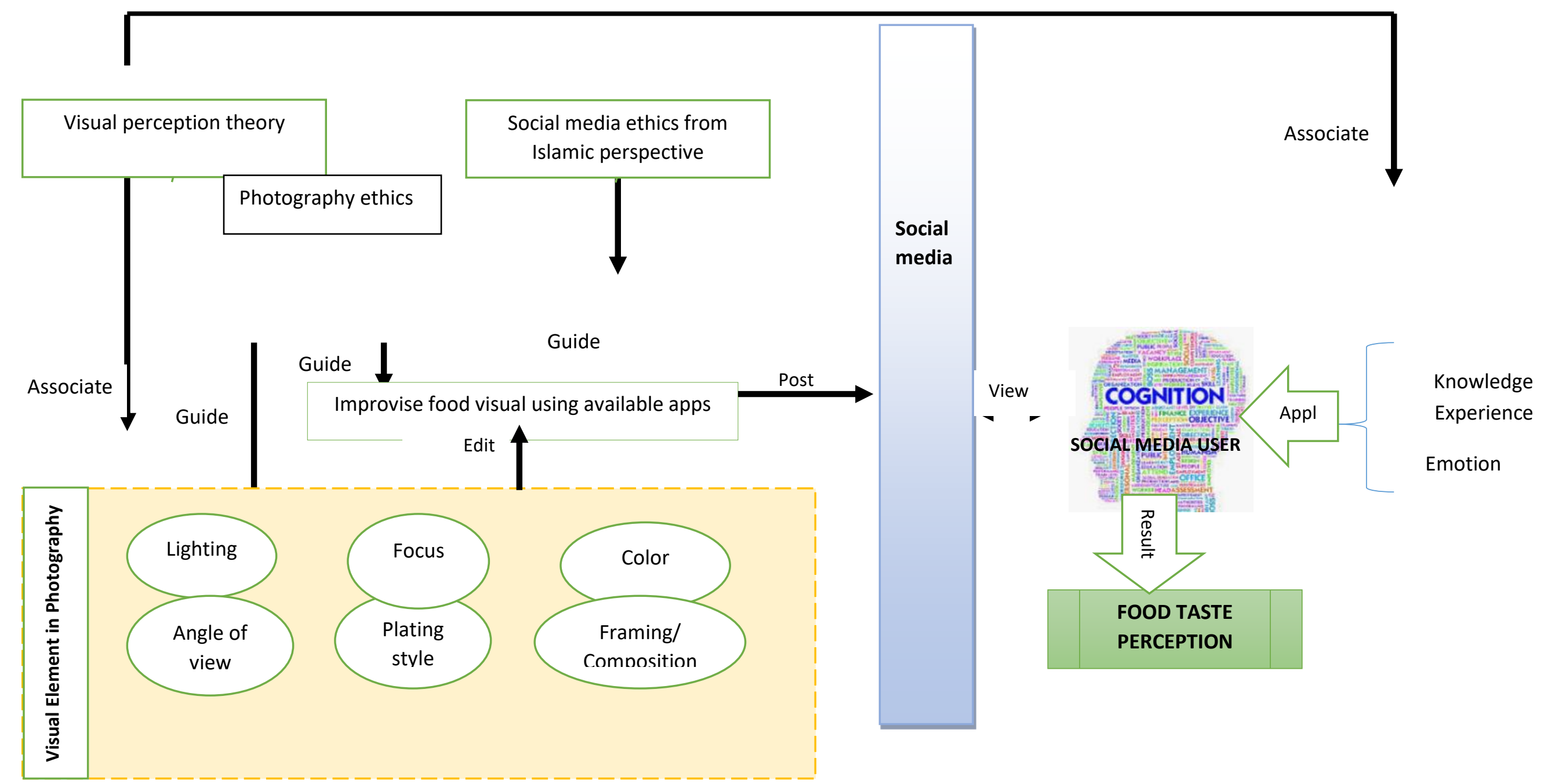

Fig.3: The taste experience conceptual model of food visual. 


\section{Conclusion}

Our study has identified the elements required to produce a food visual that could stimulate taste. We also found that our expert's insights align with findings from the literature. Additionally, based on expert knowledge and experience in food photography field, a few suggestions were advocated to complement the literature findings. In short, a proposed taste experience conceptual model of food visual has been developed as basis of producing a food visual in social media. However, we are attentive that this is an initial conceptual model, with more evidence and data collections required to validate and enhance the model. Nevertheless, it can serve as a starting point on basic requirements of image data manufacturing for taste simulation.

\section{Acknowledgements}

The authors gratefully acknowledge the help of the Ministry of Higher Education of Malaysia in providing the Fundamental Research Grant Scheme (Project Number: FRGS/1/2016/ICT04/UITM/02/2) and Universiti Teknologi MARA (UiTM) for giving the author an opportunity, support, and facilities to accomplish this project.

\section{References}

Bradley, S. (2014). The Online Importance of an Image in Digital Marketing. Retrieved August 25, 2019, from https://www.stateofdigital.com/online-importance-image-digitalmarketing/

Bruns, A., \& Burgess, J. (2015). Twitter hashtags from ad hoc to calculated publics.

Bublitz, M. G., \& Peracchio, L. A. (2015). Applying industry practices to promote healthy foods : An exploration of positive marketing outcomes 2 . Journal of Business Research, 68(12), 2484-2493. https://doi.org/10.1016/j.jbusres.2015.06.035

Chaffey, D. (2019). Global social media research summary 2019. Retrieved August 24, 2019, from https://www.smartinsights.com/social-media-marketing/social-mediastrategy/new-global-social-media-research/

Culinary, O., Alliance, T., \& Present, S. (2015). The Rise of Food Tourism Skift Team + The Ontario Culinary Tourism Alliance Culinarr Touriss. Retrieved from https://www.startupturismo.it/wp-content/uploads/2016/07/The-Rise-of-Culinary-Tourism-2.pdf

Dimara, E., \& Perin, C. (2020). What is Interaction for Data Visualization? IEEE Transactions on Visualization and Computer Graphics, 26(1), 119-129. https://doi.org/10.1109/TVCG.2019.2934283

Elson, H. (2019). The importance of photography in digital marketing. Retrieved August 25, 2019, from https://blog.learningpeople.com/the-importance-of-photography-in-digitalmarketing

Endert, A., Fiaux, P., \& North, C. (2012). Semantic Interaction for Sensemaking: Inferring Analytical Reasoning for Model Steering. IEEE Transactions on Visualization and Computer Graphics, 18(12), 2879-2888. https://doi.org/10.1109/TVCG.2012.260

Ethics, P. (2018). Photography Ethics and Why They Matter What are photography ethics? Retrieved October 26, 2020, from https://www.photoethics.org/content/2018/5/31/photography-ethics-and-why-theymatter

Feng, J., \& Yu, K. (2020). Moore's law and price trends of digital products: the case of smartphones. Economics of Innovation and New Technology, 29(4), 349-368. https://doi.org/10.1080/10438599.2019.1628509 
Ferro, S. (2014). How Fake Is Food Styling? Retrieved October 29, 2019, from https://www.fastcompany.com/3034644/how-fake-is-food-styling

Fox, A. K., Bacile, T. J., Nakhata, C., \& Weible, A. (2018). Selfie-marketing: exploring narcissism and self-concept in visual user-generated content on social media. Journal of Consumer Marketing, 35(1), 11-21. https://doi.org/10.1108/JCM-03-2016-1752

Garcia-Burgos, D., Lao, J., Munsch, S., \& Caldara, R. (2017). Visual attention to food cues is differentially modulated by gustatory-hedonic and post-ingestive attributes. Food Research International, 97(December 2016), 199-208. https://doi.org/10.1016/j.foodres.2017.04.011

Gregory, F., \& Dai, L. (2015). Multisensory Information Processing for Enhanced HumanMachine Symbiosis. In International Conference on Human Interface and the Management of Information (Vol. 9172, pp. 354-365). https://doi.org/10.1007/978-3319-20612-7_34

Gretzel, U. (2017). THE VISUAL TURN IN SOCIAL MEDIA MARKETING. TOURISMOS: AN INTERNATIONAL MULTIDISCIPLINARY JOURNAL OF TOURISM, 12(3). Retrieved from http://etem.aegean.gr/images/VOL12NO3.pdf\#page $=17$

Highfield, T., \& Leaver, T. (2016). Instagrammatics and digital methods: studying visual social media, from selfies and GIFs to memes and emoji. Communication Research and Practice, 2(1), 47-62. https://doi.org/10.1080/22041451.2016.1155332

Hull, C. (2019). 10 Best Photo Editing Apps for iPhone and Android. Retrieved November 9, 2019, from https://expertphotography.com/best-photo-editing-apps-smartphone/

Ilter, A. T., \& Karacar, P. (2019). Mobile Technology and Social Media Literacy, 180-196. https://doi.org/10.4018/978-1-7998-1534-1.ch010

Kjeldskov, J. (2019). The Encyclopedia of Human-Computer Interaction, 2nd Ed.: Mobile computing. Retrieved July 9, 2019, from https://www.interaction-

design.org/literature/book/the-encyclopedia-of-human-computer-interaction-2nded/mobile-computing

Kopcok, D. (2019). Smartphone Food Photography For Social Media. Retrieved October 18, 2019, from https://digital-photography-school.com/smartphone-food-photography-forsocial-media/

Libakova, N. M., \& Sertakova, E. A. (2015). The Method of Expert Interview as an Effective Research Procedure of Studying the Indigenous Peoples of the North. Journal of Siberian Federal University. Humanities \& Social Sciences, 1(2015 8), 114-129.

https://doi.org/10.17516/1997-1370-2015-8-1-114-129

Mansor, S. H., Narawi, A., \& Bayoumi, K. (2020). THE ETHICS OF SOCIAL MEDIA TECHNOLOGY FROM THE ISLAMIC PERSPECTIVES. In PROSIDING SEMINAR FALSAFAH SAINS DAN KETAMADUNAN (pp. 128-139). Universiti Teknologi Malaysia, Melaka, Malaysia: Akademi Tamadun Islam. Retrieved from https://www.researchgate.net/profile/Kamarul_Azmi_Jasmi/publication/342747252_P rosiding_Seminar_Falafah_Sains_dan_Ketamadunan_22_2020/links/5f3c0f2ca6fdcccc4 3d308cc/Prosiding-Seminar-Falafah-Sains-dan-Ketamadunan-22-2020.pdf\#page $=127$

Mara, U. T. (2019). SOCIAL MEDIA ADDICTION TOWARDS YOUNG ADULTS EMOTION January 2019 SOCIAL MEDIA ADDICTION TOWARDS YOUNG ADULTS, 12(January), 1-15.

Marr, D. (2010). Vision: A Computational Investigation into the Human Representation and Processing of Visual Information. MIT Press.

https://doi.org/10.7551/mitpress/9780262514620.001.0001

Nasrudin, N. H., \& Harun, A. F. (2020). A preliminary study on digital image performance to 
stimulate food taste experience, 9(5), 2154-2161.

https://doi.org/10.11591/eei.v9i5.2254

Noronha, J., Hysen, E., Zhang, H., \& Gajos, K. Z. (2011). PlateMate : Crowdsourcing Nutrition Analysis from Food Photographs. Proceedings of the 24th Annual ACM Symposium on User Interface Software and Technology. https://doi.org/10.1145/2047196.2047198

Othman, A. K., Azmi, A., \& Zainol, N. H. (2019). The Relationship between Social Media and Customer Engagement among Social Media Users, 23, 47-67.

Pearce, W., Özkula, S. M., Greene, A. K., Teeling, L., Bansard, J. S., Omena, J. J., \& Rabello, E. T. (2020). Visual cross-platform analysis: digital methods to research social media images. Information Communication and Society.

https://doi.org/10.1080/1369118X.2018.1486871

Science, T. C. (2019). Input Devices. Retrieved July 9, 2019, from https://teachcomputerscience.com/input-devices/

Seo, S., \& Yun, N. (2015). Multi-dimensional scale to measure destination food image: case of Korean food. British Food Journal, 117(12). https://doi.org/10.1108/BFJ-03-2015-0114

Serafinelli, E. (2017). Analysis of Photo Sharing and Visual Social Relationships: Instagram as a case study. Photographies, 10(1), 91-111. https://doi.org/10.1080/17540763.2016.1258657

Spence, C., Okajima, K., Cheok, A. D., Petit, O., \& Michel, C. (2015). Eating with our eyes: From visual hunger to digital satiation. International CHRIE Conference-Refereed Track, 8(2), 53-86. https://doi.org/10.1108/07378830710820925

Steichen, B., Fu, B., \& Nguyen, T. (2020). Inferring Cognitive Style from Eye Gaze Behavior During Information Visualization Usage. In Proceedings of the 28th ACM Conference on User Modeling, Adaptation and Personalization (pp. 348-352). New York, NY, USA: Association for Computing Machinery. https://doi.org/10.1145/3340631.3394881

Twente, U. (2019). Semiotic Theory INTERPRETATION OF MEANING. Retrieved from https://www.utwente.nl/en/bms/communication-theories/sorted-by-cluster/PublicRelations-Advertising-Marketing-and-Consumer-Behavior/Semiotic_Theories/

Vujovic, M. (2018). Ethics of newspaper photography, (August).

Weebly. (2019). VISUAL ELEMENTS IN PHOTOGRAPHY. Retrieved October 29, 2019, from https://chartersschoolphotographydept.weebly.com/visual-elements-inphotography.html

Williams, Y. (2018). What is Perception in Psychology? - Definition \& Theory. Retrieved November 16, 2018, from https://study.com/academy/lesson/what-is-perception-inpsychology-definition-theory-quiz.html

Witthoft, N., Sha, L., Winawer, J., \& Kiani, R. (2018). Sensory and decision-making processes underlying perceptual adaptation. Journal of Vision, 18(8), 1-20. https://doi.org/10.1167/18.8.10

Yong, J. Y. Y., Tong, E. M. W., \& Liu, J. C. J. (2020). When the camera eats first : Exploring how meal-time cell phone photography affects eating behaviours. Appetite, 154(June), 104787. https://doi.org/10.1016/j.appet.2020.104787

Zhang, L. (2018). Design and Research on Visual Communication under the Influence of Digital Media, 185(Ssehr 2017), 257-260. https://doi.org/10.2991/ssehr-17.2018.60 